\title{
The Institutional Integrity of Secondary Schools
}

\author{
Meilina Bustari \\ Educational Administration Department \\ Faculty of Educational Science \\ Yogyakarta State University \\ meilinabustari@uny.ac.id
}

\begin{abstract}
The purpose of this research was to describe the institutional integrity in secondary school. In this research, institutional integrity was observed from society support aspect, parents support aspect, and the aspect of compatibility of school program with society program. This article represented the aspect of institution integrity as one of important parts of research concerning organization health in secondary school. The result of the research showed that most teachers said that institution integrity in secondary school was categorized very high in supporting school organization health. The highest indicator which supported institutional integrity was the existence of announcementfor society and students' parents concerning school program. This phenomenon showed the existence of openness from both school and society. School was expected to get legitimation or support from society.
\end{abstract}

Keywords-institution integrity, secondary school

\section{INTRODUCTION}

School is service institution which has commitment to teaching-learning process. The main aim of school is students' learning. In fact, the existence of school itself is based on the teaching-learning activity. Schools program will be effective and can run well if they are supported by school organization which is responsive to school's need. If school is intended to be effective learning organization, school has to find ways to create structure which supports teaching-learning process constantly and improves organizational adaptation and grows organizational climate and culture which are open, collaborative, and independent [1]. Organization culture and organization climate are two contemporary perspectives which can be used to inspect school's unique character. Organization culture is an attempt to create feeling, atmosphere impression, character, or shape of an organization. Effective school organization has corporate culture which is strong and unique and the basic function of executive leadership is to form organization culture.

The health of organization in secondary school is determined by seven specific interaction patterns at school. These seven important components fulfil the basic need of social system and represent three levels of responsibility and control at school. Instruments to measure the health of school organization had been developed by Hoy and Fieldman (1987, 1999). Hoy and Fieldman elaborated the three levels which was developed by Parson into 7 specific interaction patterns at secondary school [2]. These seven patterns are then called organization health dimension.
These seven patterns are as follows: [2] institutional level which covers institutional integrity; managerial level which covers: principal influence, consideration, structure initiation, and resource support; and [1] technical level which covers morale and emphasizes academic. The details of explanation of each pattern are as follows:

1. Institutional integrity means that school and education program are cohesive. Schools are not easy to be criticized and protect interest from society and parents need. Schools are able to handle any destructive force from outside.

2. Principal influence deals with principal's ability in persuading superiors' action. Principal influence is persuasive. Principal works together with superiors effectively but simultaneously shows dependence in ideas and actions.

3. Consideration deals with principal behaviour which is friendly, supportive, open, and collegial.

4. Structure initiation means that principals'behaviour orientates towards task and achievement. Principalshave clear behaviour and hopes concerning certainty of the standard of teacher and staff performance.

5. Resource support deals with school terms concerning the sufficiency of class tools and available learning material and additional material that can be got easily.

6. Morale deals with trust in each other, belief, enthusiasm, and close friendship amongst teachers. Teacher feels the kindness from another teacher and sometimes feel that there is achievement that they achieve from their job.

7. Academic emphasis deals with school emphasis on achievement. Academic goal which is high yet achievable is a thing which is determined for students; learning environment which is order and serious; teachers believe in their students' ability to achieve; and students work hard and care about those whose academic work is good.

Those seven interaction patterns or health organization dimension explained above need to be applied and developed at schools in order to make effective school. Based on the explanation above, it can be concluded that specifically, healthy organization is organization whose technic, managerial, and institution run harmonically. This organization fulfils its need and overcomes disruptive forces from outside as it uses its power to accomplish its mission. The healthy school will be protected from pressure from society and parents which is considered to be nonsense anduseless. This protection can be got due to support from 
school board that successfully overcomes all attempts that can disrupt education process. These attempts come from interest groups that want to influence school policy. "Specifically, a healthy organization is one in which the technical, managerial, and institutional levels are in harmony. The organization is both meeting its needs and successfully coping with disruptive outside forces as it directs its energies toward its mission"[1].

On the other side, unhealthy school will be vulnerable to outside forces that spoil school climate. Teachers and school executive always get nonsense pressure and demand from parents and society. Principals do not reflect good leader and they are always oscillated by public need. Teachers do not have high work spirit. Teachers feel uncomfortable in working because they have no direction and support from the principals.

Institution integrity is one of important aspects in making healthy organization. Institution integrity is school ability to adapt to environment in order that school can be protected from unwanted things which can spoil organization climate and school quality.

\section{RESEARCH METHODOLOGY}

The purpose of this research was to describe the institution integrity in secondary schools in Bantul Regency. This institution integrity was examined from aspects of society support, parents support, and the harmony of school program and society program. This research was survey research with quantitative approach. The population of this research was teachers. The data was collected by using questionnaire method. The data was validated by using construct validity test and reliability test with Alpha Cronbach formula. The data that was collected would be analysed descriptively.

\section{RESULT AND DISCUSSION}

There were 283 teachers who were involved in this research as respondent. They were asked their opinion concerning organization health which was observed from institution integrity aspect. $54.2 \%$ of respondents said that organization health was very high, $37.2 \%$ said it was high, $7.6 \%$ of teachers said that it was low, and the rest $(1.9 \%)$ said that it was very low. The following table shows the data of institution integrity aspect in secondary schools in Bantul Regency which consists of 8 indicators.
Table 1 the distribution of frequency of institution integrity aspect.

\begin{tabular}{|c|c|c|c|c|c|c|}
\hline No & Statement & $\begin{array}{l}\mathrm{S} \\
(\%)\end{array}$ & $\begin{array}{l}\text { SR } \\
(\%)\end{array}$ & $\begin{array}{l}\mathrm{K} \\
(\%)\end{array}$ & $\begin{array}{l}\text { TP } \\
(\%)\end{array}$ & $\begin{array}{l}\text { Total } \\
(\%)\end{array}$ \\
\hline 1. & $\begin{array}{l}\text { Society support } \\
\text { activity at } \\
\text { school }\end{array}$ & 44 & 44 & 11,6 & 0,4 & 100 \\
\hline 2. & $\begin{array}{l}\text { Parents support } \\
\text { activity at } \\
\text { school }\end{array}$ & 53,4 & 41,3 & 5,3 & 0,0 & 100 \\
\hline 3. & $\begin{array}{l}\text { Schools } \\
\text { harmonize } \\
\text { education } \\
\text { program with } \\
\text { the interests of } \\
\text { parents and } \\
\text { society }\end{array}$ & 69,6 & 28,9 & 1,1 & 0,4 & 100 \\
\hline 4. & $\begin{array}{l}\text { Schools are } \\
\text { protected from } \\
\text { interest of } \\
\text { organization } \\
\text { politic }\end{array}$ & 68 & 21,2 & 4,3 & 6,5 & 100 \\
\hline 5. & $\begin{array}{l}\text { Society give } \\
\text { suggestion and } \\
\text { opinion } \\
\text { concerning } \\
\text { school policy }\end{array}$ & 33,9 & 51,3 & 14,8 & 0,0 & 100 \\
\hline 6. & $\begin{array}{l}\text { Parents support } \\
\text { the decided } \\
\text { school policy }\end{array}$ & 67 & 29,8 & 3,2 & 0,0 & 100 \\
\hline 7. & $\begin{array}{l}\text { School } \\
\text { programs are } \\
\text { announced to } \\
\text { school member } \\
\text { and society }\end{array}$ & 75,4 & 22,8 & 1,8 & 0,0 & 100 \\
\hline 8. & $\begin{array}{l}\text { Schools } \\
\text { participate in } \\
\text { surrounding } \\
\text { society }\end{array}$ & 22,3 & 58,5 & 18,8 & 0,4 & 100 \\
\hline & Mean & 54,2 & 37,2 & 7,6 & 1,9 & 100 \\
\hline
\end{tabular}

From the data above, it can be concluded that most teachers tended to describe that institution integrity was categorized as high in supporting the making of healthy school organization. As one of indicators of the health of school organization, institution integrity aspect is a thing to consider. This is because institution integrity will affect the level of society/stakeholder's trust towards related institution. Institution integrity refers to the wholeeducation program at school as system. Therefore, schools will be able 
to protect itself from any attack or pressure from external force which can disadvantage school party. So, the good cooperation between education institution and society environment need to be built.

Based on the data presented above, the percentage of indicator or statement which said thatschool programs were announced to school member and society was the highest $(75.4 \%)$. It meant that the healthy school organization had openness towards surrounding society. This openness was implemented by announcingall school programs and it was expected that school/institution will get legitimation and positive support in executing education. Principals and teachers need to get support in conducting their duties without any pressure or inappropriate involvement from individual or group. School programs were also announce tothe entire school member and therefore all civitas academia know their task and responsibility.

Respectively, the statements that showed other factors that also strengthen institution integrity aspect were statement which said that schoolsharmonizededucation programs with interest of parents and society (69.6\%), statement which said that school was protected from interest of organization politic $(68 \%)$, and statement which said that parents supportedthe decided school policy $(67 \%)$. The result of this research showed that most secondary schools in Bantul Regency had good institution integrity. This integrity was built by cooperating and communicating with society. With strong cooperation between school and society, school will be protected from pressure from outside school which can disrupt teaching-learning process. This finding was strengthened by the result of the research which showed that schools need to have institution integrity since it is important for school to have legitimation and support from society. Schools executives and teachers need support in conducting their function in harmonic way without any pressure and inappropriate involvement from individual and group outside the school [3].

On the other side, the statement which said that school participated in surrounding society had the lowest percentage $(22.3 \%)$. It meant that schools were less able to adapt to surrounding environment and therefore the level of school care towards society activity outside education field tended to be neglected. This phenomenon also showed that the relation between school and society was less harmonic since the pattern of relation was less profitable for each other. Schools should always build their institution integrity well since schools which have integrity will be protected from unexpected demand from parents and society. Schools' support towards society in all activities need to be campaigned again and therefore society will feel that they are important part of school. It can be concluded that institution integrity is important for the health of school organization since institution integrity refers to school's ability to adapt to environment and handle it with ways that preserve the maturity of school's education programs. School executives and teachers need support in conducting their function in harmonic way without pressure and inappropriate involvement from individual and group outside school. In this case, the leadership of principal is also the key to maintain social relationship, motivate, and help teachers to improve teaching-learning process [2].

\section{CONCLUSION}

Most teachers said that the health of organization in secondary school observed from institution integrity aspect was high $(54.2 \%)$. The highest indicator was the statement which said that school programs was announced to school memberand society. This phenomenon showed that schools needed to have institution integrity. In other words, it is important for school to have legitimation and support from society. School executives and teachers need support in conducting their function in harmonic way without pressure and inappropriate involvement from individual and group outside school. In other words, the image of school quality can be realized if teachers and the principal get support to work cooperatively without any inappropriate involvement from outside parties.

\section{REFERENCES}

[1] Hoy, W K \&Miskel Cecil G (2001). Educational administration. McGraw-Hill.

[2] Alig-Mielcarek, J.M. \& Hoy, W.K. (2005). Instructional Leadership: Its Nature, Meaning, and Influence. Greenwich, CT: Information Age.

[3] Daryatno dan Rianayati K. Pancawati. 2014. Administrasi pendidikan: teori, riset dan praktik. (Terjemahan). Yoagyakarta: Pustaka Pelajar.

[4] Hoy, W.K. \&Fieldman, J. (1999). "Organizational Health Profile for High School. Dalam J. Freiberg, (ED). School Climate: Measuring, Sustaining, and Improving. Philadelphia: Falmer Press.

[5] Hoy, W.K. \& Sabo, D. (1998). Quality Middle Schools: Open and Healthty. Thousand Oaks, CA: Corwin Press.

[6] Kemendiknas. 2011. Peraturan Menteri Pendidikan Nasional RI No. 44 Tahun 2010 tentang Perubahan Atas Peraturan Menteri Pendidikan Nasional No. 2 Tahun 2010 tentang Rencana Strategis Kementerian Pendidikan Nasuional Tahun 2014-2014.

[7] Lako, Andreas. 2002. Budaya Organisasi Sebagai Variabel Kunci Kesuksesan Kinerja Manajerial dan Keuangan. Prosiding Unika Soegijapranata

[8] Setya Raharja. 2012. Makalah diajukan dalam Konferensi dan Seminar Internasional "ICEMAL" padaTanggal 4 \& 5 Juli 2012, di Malang JawaTimur.

[9] Slamet .TT. Manajemen berbasis sekolah. Diktat kuliah. UNY: S3 Manajemen Pendidikan

[10] Sugiyono. 2011. Metode penelitian kombinasi (Mixed Methods). Bandung; Alfa Beta. 